\title{
Students' Rights on Education and Teachers' Professionalism
}

\author{
Harpani Matnuh \\ Lambung Mangkurat University \\ Banjarmasin, Indonesia \\ harpani.matnuh@yahoo.com
}

\begin{abstract}
Article 60 of Legislation No.39, 1999 on Human Rights affirms that; Every child is entitled to education and teaching in the framework of personal development according to his/her interests, talents and level of intelligence. The educational rights of learners are not merely to get an education, but they have the right to get the subject matter translation correctly, the comfortable learning process, safe, democratic, fair, transparent in accordance with the norms that apply. Therefore Government Regulation No.74 Year 2008 on Teacher confirms that; A teacher must have competencies including pedagogic competencies, personality competence, social competence, and professional competencies which are gained through professional education. Teachers as professional educators have the main task that is; educate, teach, guide, direct, train, assess, and evaluate learners in early childhood education formal education, basic education, and secondary education. Teachers who lack competence and are not professionals in teaching often lead to violations of the educational rights of learners and even violations of law.
\end{abstract}

Keywords-students' rights on education and teachers' competence

\section{INTRODUCTION}

Students' rights to education are not just the moral rights that must be met, but these are also the constitutional rights as guaranteed in Article 28C (1) Constitution of the Republic of Indonesia of 1945 that "Everyone has the right to develop his/herself through the fulfillment of basic needs. He/she has the rights on education and use of science and technology, art and culture, in order to improve the quality of life and for the welfare of mankind [1].

Furthermore, Legislation, No.11 The year 2005 on the rights on education mentions that one of the rights that must be given by the government to students is: "The students' rights to acquire and experience education and protection in order that they can grow and develop optimally in accordance with the status and dignity",

On the basis of the formally juridical rules, the National Education System functions to fulfill the students' rights on education in developing their competencies and building their personalities for being adult humans who are faithful and devoting to God Almighty, noble, healthy, knowledgeable, capable, creative, independent, and become democratic and responsible citizens.
A reality that cannot be denied is when speaking of the implementation of national education, then the role of teachers cannot be separated from the world of education in school. In a simple sense, the teacher is the one who gives knowledge to students both formally and non-formally. This is because teachers are at the forefront in the implementation of education. Teachers are directly dealing with learners in the giving of basic human rights (basic) education.

The teachers and students are two different sides but cannot be separated from one to another. At school, the teachers have double functions. The first function is that they have the function as the second parents who build personalities for their students to be good adult persons. The second function is that they are educators who transfer knowledge and skill and give guidance, as their efforts to develop their students' potency optimally.

Article 1 (1), Legislation No.14 Year 2005 on "Teachers and Lecturers" confirms that "Teachers are professional educators with the primary task of educating, teaching, guiding, directing, training, assessing and evaluating the students on early childhood education, formal education, elementary education and secondary education [2].

Furthermore, Article 8 of Legislation No. 14 The year 2005 states that "Teachers are required to have academic qualifications, competence, teaching certificate, physically and mentally healthy, and have the ability to realize the goal of national education". Thus, becoming a professional teacher should meet a number of requirements and capabilities demanded. A person who is not a professional, he/she can result in violations of the students' rights on education [2].

Granting the educational rights of learners is a condition sinequanon as a constitutional mandate that must be enforced. Human Rights Education learner not only in the form of right to get education, but the learners also have the right to be educated by professional teacher so that learners will get the learning material correctly, treatment of safe and comfortable, without discriminative, get objective assessment, regardless of the element of pressure, physically or mentally.

Thus a teacher who does not possess the competence and is not professional may not be able to carry out the learning process properly and correctly and has the potential violation of the rights of learners in receiving learning in school. 


\section{METHODS}

The method of writing is a normative legal research which is to conduct research by using the study and analysis of various laws and regulations, legal principles related to the professionalism of teachers and the rights of learners.

\section{DISCUSSION}

\section{A. Learners' Right to Education}

Article 1 of Legislation of the Republic of Indonesia Number 39 Year 1999 on Human Rights states that "a set of rights bestowed by God Almighty in the essence and being of humans as creations of God which must be respected, held in the highest esteem and protected by the state, law, Government, and all people in order to protect human dignity and worth." [3].

Ref. [4] states that a learner is anyone who receives influence from a person or a group and has sense and logic. The learner is an important human element in educational interaction activities.

Learners as part of the potential future generation need to be nurtured and guided through formal education conducted by teachers as educators in a professional manner. On the other hand, learners are homo educandum who have a set of educational rights that must be met by the State, government, law, and teachers as implementers of education in schools.

Learners' right to education constitute the mandate of the Constitution Article 28C of the 1945 Constitution, namely the right to develop themselves, receive education, benefit from science and technology, art and culture, advance themselves collectively [1].

Article 60 of Legislation No. 39 The year 1999 on Human Rights states that "Every child has the right to access education and schooling which befits his interests, talents, and intellectual capacity" [3].

Furthermore, to understand the basic education of learners, it can be seen from Chapter II of Legislation No. 39 The year 1999 related to the educational rights of learners which include [3];

- Right to grow and develop properly,

- The right to education and to educate them,

- Right to benefit from science, technology, art, and culture,

- The right to obtain the necessary information correctly,

- Right to struggle for self-development,

- Right to justice without discrimination,

- Right to express opinions,

- Right to security,

- The right to education and instruction in accordance with their interests, talents and intelligence level,
- The right not to be subjected to torture and inhuman punishment,

Based on the description, learners' right to education means a set of rights attached to learners to obtain the full educational service in accordance with the dignity and worth. The fulfillment of learners' right to education is not only made in the fulfillment of learners' education, but also includes all learning activities to respect and protect the rights of learners in order to grow, develop, and participate optimally in accordance with the dignity and worth of humanity.

\section{B. Teacher Professionalism}

Article 1 of Legislation No.14 Year 2005 on Teachers and Lecturers states that "Teachers are professional educators with the main task of educating, teaching, guiding, directing, training, assessing and evaluating learners in early childhood education through formal education, primary education, and secondary education [2].

In order for teachers to perform the main tasks as professionals, a teacher must have academic qualifications, competence, educator certificate, physical and spiritual health, and have the ability to realize the goals of national education. Therefore, to be a professional teacher requires a set of knowledge, skills, and behaviors that must be possessed, experienced, mastered and actualized by teachers in performing professional duties.

Teacher competence as referred to in Article 10 of Legislation No.14 Year 2005 is a combination of the ability of knowledge, attitude, and skills covering pedagogic competence, personality competence, social competence, and professional competence obtained through professional education [2].

\section{1) Pedagogic Competences}

Pedagogic competence requires the ability of teachers to understand the learners deeply which includes an understanding of child development psychology, while the implementation of learning includes the ability of teachers in designing learning, implementing learning, assessing learning process and outcomes, and making improvements in a sustainable manner. Article 3 (4) of Government Regulation No.74 Year 2008 regarding teachers states that pedagogical competencies that must be owned by a teacher include at least the following abilities [5]:

- Understanding on insights or educational foundation

- Understanding on learners

- Curriculum or syllabus development;

- Learning design;

- Implementation of educational and dialogical learning

- Utilization of learning technology;

- Evaluation of learning outcomes; and

- Development of learners to actualize their potentials 


\section{2) Personality Competences}

Personality competence characterizes a person's behavior. Ref. [6] says that "An important factor for a teacher is his/her personality. That personality will determine whether he/she is a good educator and coach for his/her learners or will be a destroyer for the future of learners, especially for young learners (elementary level) and those who are experiencing mental shock (intermediate level). Article 3(4) of Government Regulation No.74 Year 2008 mentions personality competences as referred to at least the following personality [5]:

- Having faith and obeying the religious teaching

- Having a noble character

- Being wise and prudent

- Being democratic

- Being tough

- Being authoritative

- Being stable

- Being matured

- Being honest

- Being fair

- Being role models for learners and society

- Objectively evaluating their own performance

- Developing themselves independently and sustainably

\section{3) Social Competences}

Article 28 (3) of Government Regulation No.13 Year 2015 on the National Education Standard states that "social competence is the ability of teachers as part of the community to communicate and get along effectively with educators, fellow educators, and the surrounding community" [7]. Further Article 3(6) of Government Regulation No.74 of 2008 mentions that the teachers' social competence as a part of the community at least includes the ability to [5]:

- Communicate in oral and written form, and/or with polite gestures;

- Use communication and information technology functionally;

- Socialize effectively with learners, fellow educators, education personnel, education unit leaders, parents of learners;

- Associate politely with the surrounding community by heeding the prevailing norms and value system

- Apply the principle of true brotherhood and spirit of togetherness.

\section{4) Professional Competence}

Ref. [8] says that "professional has the same meaning as the word 'occupation' or work that requires expertise gained through special education or training".

Teacher professionalism is the ability of teachers to perform their main duties as educators and teachers including the ability to plan, perform, and implement learning evaluations. Therefore, professional teachers become the hope of all parties because the position of teachers in education is at the forefront in determining the quality of national education. Furthermore, Article 3 (7) of Government Regulation No. 74 The year 2008 on teachers explains that the professional competence of teachers include the ability of teachers in mastering knowledge in science, technology, and/or art and culture that they focus on, which at least includes the mastery of [5]:

- Subject matter in a broad and in-depth manner which is consistent with the standard content of the educational unit, subjects, and/or group of subjects to be taught; and

- The concepts and methods of relevant scientific, technological or art disciplines, which are conceptually coherent with the educational program, subject, and/or group of subjects to be taught.

\section{CONCLUSION}

The learner is everyone who receives influence from a person or group of people who hold education. Learners are potential future generations who need to be nurtured and guided by professional teachers in achieving the goals of national education.

- The rights of learners are not merely to get formal education in schools, but the basic rights of the participants include a set of educational rights attached to the learner in order to obtain educational services and learning processes properly, comfortably, safely, democratically, fairly, transparent and in accordance with their interests, talents and their intelligence levels

- When carrying out formal learning process in school, a teacher must have pedagogic competence, personality competence, social competence and professional competence.

- Teachers are professional educators with the main task of educating, teaching, guiding, directing, training, assessing, and evaluating learners in early childhood informal education, basic education, and secondary education.

- Various cases of violation of the human rights of learners and lead to violations of law are often committed by teachers who lack competence and professionalism.

\section{REFERENCES}

[1] Undang-Undang Dasar Negara Kesatuan Republik Indonesia Tahun 1945 .

[2] Undang-Undang Nomor 14 Tahun 2005, tentang; Guru dan Dosen 
[3] Undang - Undang Nomor 39 Tahun 1999 tentang; Hak Asasi Manusia.

[4] Syaiful Bahri Djamarah, 2010, Guru \& Anak di dalam Interaksi Edukatif, Jakarta, Renika.

[5] Peraturan Pemerintah Nomor 74 Tahun 2008, tentang Guru.

[6] Zakiah Darajat, 2013, Kepribadian Guru,Jakarta, Bulan Bintang.
[7] Peraturan Pemerintah Nomor 13 Tahun 2015, tentang Standar Nasional Pendidikan Etika Guru.

[8] Iskandar Agung, 2014, mengembangkan Profesionalitas Guru, Upaya Meningkatkan Kompetensi dan Profesionalisme Kinerja Guru, Jakarta, Bee Media Pustaka. 